\title{
Evaluasi Desain Antarmuka Portal Akademik Menggunakan Metode Heuristic Evaluation
}

\author{
Murdiaty, Angela, Chatrine Sylvia \\ Program Studi Sistem Informasi, STMIK Mikroskil, Medan, Indonesia \\ Email: ${ }^{1}$ murdiaty@mikroskil.ac.id, ${ }^{2}$ angela.woen@mikroskil.ac.id, ${ }^{3}$ chatrine.sylvia@mikroskil.ac.id
}

\begin{abstract}
Abstrak
Kegiatan mengevaluasi rancangan antarmuka merupakan bagian dari interaksi manusia dan komputer (HCI-Human Computer Interaction). Fokus penelitian ini adalah melakukan evaluasi heuristic pada desain aplikasi antarmuka sebuah portal akademik untuk menentukan sejauh mana portal akademik tersebut memenuhi konsep kegunaan (usability) desain antarmuka. Portal akademik merupakan website yang diakses civitas akademika melalui web browser. Portal ini dapat diakses oleh mahasiswa, dosen pengampu mata kuliah, dosen wali, dosen pembimbing Tugas Akhir, serta civitas akademika yang lain seperti: Bagian Administrasi Akademik (BAA), Program Studi, Perpustakaan, Bagian Kemahasiswaan dan Bagian Administrasi Umum dan Kepegawaian (BAUK). Penelitian ini memanfaatkan penggunaan metode evaluasi heuristic sebagai suatu metode dalam melakukan evaluasi terhadap suatu sistem yang membangun hubungan antara manusia dan komputer (man-machine system) dengan mengkaitkan pada kemudahan penggunaan (usability) serta severity ratings. Penelitian ini melibatkan beberapa orang evaluator yang akan melakukan penilaian dengan mengisi heuristic checklist. Hasil yang diharapkan yaitu para evaluator dapat menemukan berbagai permasalahan terkait dengan kemudahan penggunaan yaitu mengevaluasi antarmuka pengguna yang bersifat umum dan memastikan menu-menu yang terdapat pada sistem dapat berfungsi semestinya, serta penggunaan tata bahasa yang tidak konsisten. Hasil ini nantinya diharapkan dapat digunakan oleh para pengembang sistem portal akademik Mikroskil untuk melakukan penyempurnaan terhadap portal akademik yang digunakan saat ini.
\end{abstract}

Kata Kunci: Evaluasi Heuristic, Severity Rating, Portal Akademik, Heuristic Checklist, Usability

\section{Abstract}

Evaluation of interface design is part of human and computer interaction (HCI-Human Computer Interaction). The focus of this study is to conduct heuristic evaluations on the interface design of an academic portal to determine the extent to which the academic portal meets the concept of usability. Academic portal is a website accessed by academics through a web browser. This portal can be accessed by students, lecturers, academic supervisors, Final Project supervisors, and other academics such as: Academic Administration Section (BAA), Study Programs, Libraries, Student Affairs, and Public Administration and Personnel Section (BAUK). This study uses heuristic evaluation as an approach in evaluating a human-machine system (manmachine system) in relation to academic portal ease of use (usability) and also severity ratings in addition to heuristic checklist. This study involved several evaluators who would conduct an assessment by filling in the heuristic checklist. The expected results with the evaluator's heuristic evaluation method found usability problems related to the general interface. These results are expected to be used by Mikroskil's academic portal system developers to make improvements to the academic portal currently in use.

Keywords: Heuristic Evaluation, Severity Rating, Academic Portal, Heuristic Checklist, Usability

\section{PENDAHULUAN}

Portal Akademik Mikroskil yang disingkat menjadi MIKA merupakan portal yang diakses oleh civitas akademika melalui web browser. Portal ini dapat diakses oleh mahasiswa, dosen pengampu mata kuliah, dosen wali, dosen pembimbing Tugas Akhir, serta civitas akademika yang lain seperti: Bagian Administrasi Akademik (BAA), Program Studi, Perpustakaan, Bagian Kemahasiswaan, dan Bagian Administrasi Umum dan Kepegawaian (BAUK). Bagi dosen, fitur yang dapat diakses meliputi fitur Lihat Data Mahasiswa, Persetujuan Pengisian KRS, Persetujuan Pengeditan KRS, Pencarian KRS Mahasiswa, Berita Acara dan Absensi Perkuliahan, Tugas Akhir/Tesis, Profil Dosen, Download Berkas, Upload Berkas, Panduan Dosen, dan Koreksi Nilai serta informasi lainnya. Ketika pengguna mengakses sebuah halaman website, maka pada saat itulah terjadi interaksi antara pengguna dengan komputer atau perangkat yang digunakan untuk membuka atau mengakses web browser tersebut. Interaksi ini biasanya disebut sebagai interaksi antara manusia dengan komputer (human computer interaction).

HCI merupakan bidang lintas disiplin ilmu yang berhubungan dengan, teori, rancangan, penerapan dan evaluasi mengenai cara yang dipakai oleh manusia dalam berinteraksi dengan komputer. Salah satu metode yang dapat digunakan dalam memeriksa permasalahan yang terkandung dalam suatu antarmuka pengguna adalah metode evaluasi heuristic. Metode evaluasi heuristic mencakup beberapa prinsip kegunaan seperti sepuluh prinsip kegunaan Jacob Nielsen. Metode evaluasi heuristic merupakan metode evaluasi yang sering dimanfaatkan oleh para ahli HCI untuk memberikan petunjuk terhadap masalah usability [1]. Untuk memudahkan dalam melakukan evaluasi terhadap antarmuka pengguna dengan menggunakan metode evaluasi heuristic, penelitian ini menggabungkan penggunaan heuristic checklist dengan severity ratings. Severity ratings biasanya dihubungkan dengan tingkat keseriusan atau tingkat keparahan permasalahan yang muncul ketika melakukan kegiatan evaluasi di mana tingkat keparahan yang muncul bisa bervariasi. Terdapat 5 (lima) kategori nilai pada severity ratings, yang dimulai dari nilai 0 yang berarti tidak ada masalah sampai dengan nilai 4 yang berarti sangat penting untuk memperbaiki permasalahan dan perbaikan ini harus menjadi prioritas utama [2]. 
Portal Akademik Mikroskil merupakan sistem utama yang penting dan vital digunakan sehari-hari oleh seluruh dosen dan civitas akademika STMIK-STIE Mikroskil untuk mendukung kegiatan administrasi perkuliahan. Portal yang dibangun untuk melayani keseluruhan tugas utama seorang dosen seharusnya dapat memberikan layanan yang berkualitas dan informasi yang akurat kepada penggunanya. Kualitas portal yang baik direfleksikan dengan adanya usability yang baik, sehingga semakin baik usability suatu sistem maka semakin mudah dan semakin puas pengguna dalam menggunakan Portal Akademik. Dengan demikian, penelitian ini menjadi penting dilakukan untuk mengetahui dan memahami berbagai permasalahan usability yang muncul pada Portal Akademik Mikroskil serta mengidentifikasi solusi untuk menyelesaikan permasalahan tersebut. Setelah berhasil mengidentifikasi berbagai permasalahan maka diharapkan adanya peningkatan terhadap tingkat usability Portal Akademik dengan mengimplementasikan perbaikan yang mengacu pada rekomendasi perbaikan terhadap permasalahan yang ditemukan. Penelitian ini menggunakan metode evaluasi heuristic yang menggabungkan penggunaan heuristic checklist dan severity ratings sehingga diharapkan dapat menemukan permasalahan usability yang berkaitan dengan antarmuka Portal Akademik MIKA yang nantinya dapat diusulkan saran perbaikan kepada pihak pengembang sistem dengan harapan Portal Akademik MIKA dapat lebih menunjang kebutuhan pengguna.

\section{TEORITIS}

\subsection{Evaluasi Heuristic}

Evaluasi heuristik (heuristic) adalah metode informal untuk mengkaji kegunaan suatu aplikasi atau software di mana sejumlah evaluator disajikan dengan desain antarmuka dan diminta untuk mengomentarinya. Pendekatan ini diciptakan oleh Nielsen dan Molich pada tahun 1990 dan menjadi cara evaluasi yang cukup populer dan banyak digunakan saat ini. Evaluasi heuristik dilakukan dengan melihat sebuah tampilan antarmuka dan mencoba mengemukakan pendapat tentang apa yang baik dan buruk dari antarmuka tersebut. Idealnya, orang akan melakukan evaluasi sesuai dengan aturan tertentu seperti yang tercantum dalam dokumen pedoman umum. Namun, kebanyakan orang mungkin melakukan evaluasi heuristik berdasarkan intuisi dan akal sehat mereka sendiri [3].

Hasil dari evaluasi heuristik akan jauh lebih baik jika terdapat beberapa orang yang melakukan evaluasi, dan mereka harus melakukan evaluasi tersebut secara independen satu sama lain. Jumlah evaluator yang direkomendasikan dalam melakukan evaluasi heuristik adalah sebanyak tiga sampai lima evaluator dan sumber daya tambahan dapat dimanfaatkan untuk metode evaluasi alternatif. Keuntungan dari evaluasi heuristik adalah: murah, bersifat intuitif dan mudah memotivasi orang untuk melakukannya, tidak memerlukan perencanaan terlebih dahulu, dan dapat digunakan di awal proses pengembangan [3].

Terdapat sepuluh prinsip umum untuk desain interaktif yang dikembangkan Nielsen. Prinsip-prinsip tersebut disebut "heuristik" karena merupakan aturan umum dan bukan pedoman kegunaan khusus. Kesepuluh prinsip tersebut adalah [1]:

1. Visibilitas status sistem

2. Kesesuaian antara sistem dan dunia nyata

3. Kontrol dan kebebasan pengguna

4. Konsistensi dan standar

5. Pencegahan kesalahan

6. Pengenalan alih-alih mengingat

7. Fleksibilitas dan efisiensi penggunaan

8. Desain estetis dan minimalis

9. Bantu pengguna mengenali, mendiagnosis, dan memulihkan dari kesalahan

10. Bantuan dan dokumentasi

\subsection{Penelitian Terdahulu}

Penelitian terdahulu berfungsi untuk memberikan penjelasan mengenai pembahasan penelitian yang telah dilakukan oleh peneliti sebelumnya. Seperti penelitian yang dilakukan oleh Putu Krisnayani, I Ketut Resika Arthana, I Gede Mahendra Darmawiguna (2016) bertujuan untuk menganalisis tingkat usability dan menentukan rancangan layout pada website UNDIKSHA menggunakan metode heuristic evaluation dengan 10 variabel usability. Hasil dari penelitian ini difokuskan pada perlu adanya perubahan warna tampilan untuk membedakan antara link yang sudah pernah diakses dan belum pernah diakses, menyediakan bantuan untuk membantu pengguna menangani kesalahan, menyajikan submenu dan ikon-ikon secara konsisten, memberikan keterangan yang sesuai pada tautan link, membedakan font agar judul dan deskripsi kalimat dapat dibedakan, menyediakan dokumentasi yang lengkap, serta melengkapi website dengan menu Bantuan untuk mempermudah pengguna dalam mencari solusi apabila pengguna menjumpai kesalahan. Selain itu, dari hasil kuisioner yang telah diperoleh, perlu ditekankan perbaikan pada SOP (Standar Operasional Prosedur) pelayanan agar selalu mendapatkan informasi yang akurat dan up-to-date [4].

Kemudian, terdapat pula penelitian Ricky Firmansyah (2016) dilakukan untuk menentukan sejauh mana daya guna (usability) desain antarmuka dari aplikasi My Indihome versi 1.5 pada platform Android menggunakan 
evaluasi heuristic. Selanjutnya, hasil dari evaluasi ini digunakan PT. Telkom sebagai acuan untuk melakukan perbaikan dalam pembaruan (update) aplikasi, terutama pada bagian antarmuka pengguna. Penelitian ini memperoleh temuan bahwa antarmuka aplikasi MyIndiHome telah mampu memberikan kenyamanan bagi pengguna secara umum tetapi masih dapat dilakukan perbaikan aplikasi dalam hal kemudahan penggunaan dan keakuratan informasi [5].

Dino Caesaron (2015) memfokuskan penelitiannya pada penggunaan metode evaluasi terutama kemudahan penggunaan (usability) dalam hubungannya dengan interaksi manusia dan komputer. Objek penelitian yang diangkat adalah portal mahasiswa Universitas X dan metode yang digunakan adalah evaluasi heuristic versi Molich dan Nielsen. Dari evaluasi heuristic yang sudah dilakukan, didapatkan bahwa secara umum desain antar muka (interface) pada portal mahasiswa sudah cukup baik namun masih perlu peningkatan dalam hal kemudahan penggunaan (usability) dan terdapat beberapa poin dalam karakteristik kemudahan penggunaan (usability) yang perlu dikaji lebih lanjut [6].

Lalu, ada penelitian yang dilakukan oleh Mochammad Imam Sya'roni, Agi Putra Kharisma, Faizatul Amalia (2018) untuk mengetahui permasalahan yang dihadapi oleh web FILKOM APPS dan untuk mengetahui perbandingan hasil evaluasi antara metode heuristic evaluation dan think aloud. Penelitian ini menghasilkan informasi bagi pihak pengembang web untuk meningkatkan usabilitas dan fungsionalitas fitur-fitur yang tersedia. Evaluasi yang dilakukan oleh para ahli HCI menemukan permasalahan usabilitas yang bersifat umum terkait dengan antarmuka pengguna dan juga masih terdapat beberapa menu-menu yang tidak dapat berfungsi secara normal, serta penggunaan bahasa yang tidak konsisten. Hasil yang sama juga diperoleh berdasarkan metode think aloud yang dilakukan oleh para pengguna [7].

Deden Hardan G, Andrie Prajanueri Kristianto, Mahmudi, Henderi (2018) melakukan evaluasi secara berkala untuk meningkatkan kualitas aplikasi driver Gojek agar aplikasi tersebut memenuhi standar aplikasi yang baik. Metode evaluasi yang dipilih adalah heuristic evaluation untuk mencari masalah usabilitas sistem dengan melibatkan beberapa responden. Tujuan penelitian ini adalah untuk mengetahui apakah aplikasi tersebut sudah dapat diterima secara baik oleh masyarakat. Ternyata, hasil penelitian menunjukkan poin-poin yang perlu ditingkatkan yaitu pada rule User control and freedom yang menekankan pada aspek pengguna dapat memilih pekerjaan sesuai kebutuhan serta rule Help users recognize, diagnose, and recover from errors yang menekankan pada pemberian saran dan rekomendasi saat driver melakukan kesalahan [8].

Berikutnya, penelitian Suci Indrawati Irwan, Imas Sukaesih Sitanggang, dan B. Mustafa (2015) bertujuan untuk mengevaluasi usabilitas Sistem Informasi Manajemen Penerimaan Koleksi Deposit pada Perpustakaan Nasional Republik Indonesia berdasarkan pendekatan evaluasi heuristic dan memberi rekomendasi terhadap aspek usabilitas untuk melakukan perbaikan sistem. Hasil rekomendasi dari penelitian ini dapat memberikan sumbangan pemikiran bagi pimpinan Perpustakaan Nasional RI untuk mengambil keputusan dalam mengembangkan dan memperbaiki sistem informasi manajemen penerimaan koleksi deposit di Perpustakaan Nasional RI serta memberikan kontribusi teoritis bagi perkembangan ilmu perpustakaan dan ilmu teknologi informasi, khususnya dalam bidang teknologi informasi untuk perpustakaan [9].

Selain itu, ada pula penelitian Bella Aulia M, M. Chandra Saputra, Aryo Pinandito (2016) yang menerapkan metode evaluasi heuristic pada website Universitas Brawijaya. Tujuannya adalah untuk mengetahui hasil uji preferensi pengguna pada website Universitas Brawijaya. Para evaluator yang merupakan expert dalam bidangnya menemukan sebanyak 53 permasalahan yang berkaitan dengan usabilitas. Permasalahan tersebut terdiri atas permasalahan mayor dengan prioritas perbaikan tingkat tinggi pada heuristik visibility of system status, match between system and real world, recognition rather than recall dan flexibility and efficiency of use; permasalahan minor dengan prioritas perbaikan tingkat rendah pada heuristik consistency and standards, error Prevention, aesthetic and minimalist design, help users recognize, diagnose, and recover from errors dan help and documentation; serta tidak ditemukan permasalahan pada heuristik User control and freedom [10].

Dari luar negeri, ada penelitian Joel S. Mtebe, Mussa M. Kissaka (2015) menyajikan kegunaan heuristic komprehensif yang menggabungkan kegunaan antarmuka, efektivitas mengajar dan movitasi untuk belajar. Heuristic divalidasi melalui evaluasi para ahli dari Universitas Dar Es Salaam dan Shuledirect systems di Tanzania. Heuristic yang diusulkan berhasil mengungkap beberapa masalah kegunaan. Temuan dari penelitian ini telah menunjukkan bahwa heuristic yang diusulkan sesuai dan efektif untuk digunakan untuk mengevaluasi Learning Management System (LMS) yang digunakan di negara Afrika [11].

Terakhir, terdapat penelitian yang dilakukan oleh Jose Miguel Toribo Guzman, Alicia Gracia Holgado, Felipe Soto Perez, Francisco J. Garcia Penalvo, Manuel A. Franco Martin (2016). Tujuan dari penelitian ini adalah evaluasi kegunaan dari SocialNet, sebuah jejaring sosial pribadi untuk memantau perkembangan harian pasien oleh kerabat mereka. Penelitian ini menyajikan fase pertama dimana digunakan evaluasi heuristic ganda sebagai metode mengevaluasi kegunaan. Evaluasi telah memberikan data tentang asal usul masalah kegunaan SocialNet, terutama terkait dengan konsistensi, desain, dan privasi. Temuan telah membantu mendesain ulang beberapa aspek SocialNet dan untuk memberikan interaksi yang efektif, efisien dan pengalaman yang memuaskan bagi pengguna. Penggunaan evaluasi heuristik akan dilengkapi dengan tes pengguna yang akan dilakukan dalam fase kedua dari studi kegunaan, yang tidak dibahas dalam makalah ini [12]. 


\section{ANALISA DAN PEMBAHASAN}

Adapun langkah-langkah yang dilakukan dalam kegiatan penelitian ini meliputi:

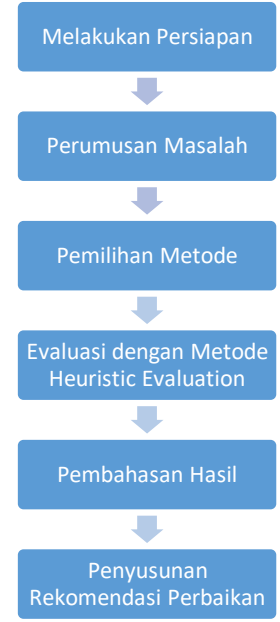

Gambar 1. Tahapan Kegiatan Penelitian

Adapun penjelasan dari langkah-langkah yang dilakukan dalam kegiatan penelitian seperti yang tampak pada gambar 1 sebagai berikut:

1. Melakukan Persiapan

Pada tahap awal ini, tim peneliti menentukan objek dan lokasi penelitian. Objek pada penelitian ini yaitu Portal Akademik Mikroskil (MIKA) dan lokasi penelitian dilakukan di lingkungan kampus STMIK-STIE Mikroskil.

2. Perumusan Masalah

Peneliti melakukan observasi terhadap objek penelitian kemudian dari hasil observasi tersebut, didapatkan rumusan masalah yang akan dijawab dalam penelitian ini.

3. Pemilihan metode

Tim peneliti melakukan pemilihan metode yang akan digunakan dalam penelitian. Hasil diskusi tim akhirnya memilih metode Heuristic Evaluation.

4. Evaluasi dengan metode Heuristic Evaluation

Untuk evaluasi menggunakan heuristic evaluation, evaluator sejumlah tiga orang dipilih berdasarkan pemahamannya terhadap konsep usability. Supaya pengujian usability dapat berjalan dengan lancar, maka diperlukan suatu skenario pengujian yang baik, di mana skenario pengujian untuk melakukan evaluasi menggunakan metode heuristic evaluation terdiri dari langkah berikut:

a. Memperkenalkan diri dan menyampaikan tujuan penelitian kepada evaluator.

b. Memberikan heuristic checklist kepada evaluator.

c. Waktu yang diberikan kepada evaluator untuk melakukan evaluasi sekitar satu sampai tiga jam.

d. Jika evaluator menemukan permasalahan usabilitas, evaluator dapat mencatat temuan permasalahan tersebut pada kolom komentar yang telah disediakan dalam form heuristic checklist.

e. Evaluator kemudian mengisi nilai pada kolom severity ratings yang telah tersedia sesuai dengan tingkat keparahan permasalahan yang ditemukan.

5. Pembahasan Hasil

Pada tahap ini, tim peneliti merumuskan berbagai permasalahan yang diperoleh dari form heuristic checklist yang telah diisikan oleh evaluator.

6. Penyusunan Rekomendasi Perbaikan

Pada tahap akhir ini, tim peneliti merumuskan kesimpulan yang didapat dari pembahasan hasil tersebut dan merumuskan rekomendasi perbaikan berdasarkan saran dari evaluator yang didukung oleh beberapa artikel dan studi pustaka dimana saran-saran tersebut dapat diberikan kepada tim pengembang sistem Mikroskil.

Setelah ketiga evaluator yang terpilih selesai mengisi heuristic checklist dengan menggunakan severity rating dan memberikan komentar terhadap permasalahan yang ditemukan pada saat mengevaluasi Portal Akademik Mikroskil, maka hasil evaluasi dari ketiga evaluator tersebut dikumpulkan dan direkapitulasi. Hasil evaluasi secara keseluruhan menemukan sejumlah tiga puluh empat permasalahan. Berdasarkan hasil evaluasi yang sudah dilakukan, maka persebaran temuan permasalahan dapat dilihat pada Tabel 1.

Tabel 1. Persebaran Temuan Permasalahan

\begin{tabular}{clc}
\hline No & \multicolumn{1}{c}{ Prinsip Heuristic } & Jumlah Temuan Masalah \\
\hline 1 & Visibilitas status sistem & 3 \\
2 & Kesesuaian antara sistem dan dunia nyata & 3 \\
\hline
\end{tabular}




\begin{tabular}{llc}
\hline 3 & Kontrol dan kebebasan pengguna & 2 \\
4 & Konsistensi dan standar & 6 \\
5 & Pencegahan kesalahan & 5 \\
6 & Pengenalan alih-alih mengingat & 4 \\
7 & Fleksibilitas dan efisiensi penggunaan & 4 \\
8 & Desain estetis dan minimalis & 2 \\
9 & Bantu pengguna mengenali, mendiagnosis, dan & 3 \\
& memulihkan dari kesalahan & \\
10 & Bantuan dan dokumentasi & 2 \\
\multicolumn{2}{r}{ Total Temuan Permasalahan } & $\mathbf{3 4}$ \\
\hline
\end{tabular}

Pada prinsip heuristic yang pertama, yaitu visibilitas status sistem ditemukan sebanyak tiga permasalahan yang masuk ke dalam kategori Minor. Permasalahan pertama yang ditemukan adalah tidak disediakan informasi yang memberitahukan posisi pengguna saat ini dalam Portal Akademik. Hal ini membuat pengguna pemula yang belum familiar dengan tampilan Portal Akademik mengalami kebingungan mengenai posisinya saat ini dalam situs Portal Akademik. Sebaiknya, ditambahkan informasi tersebut pada bagian atas halaman Portal Akademik (misalnya: menambahkan breadcrumb) sehingga bagi pengguna pemula dapat memahami dimana posisi pengguna saat ini [13]. Permasalahan kedua adalah tidak ada informasi mengenai keterlambatan memuat informasi sehingga pengguna terus menunggu informasi tersebut tanpa ada kejelasan. Oleh karena itu, lebih baik tampilkan informasi mengenai waktu delay pada halaman Portal Akademik sehingga pengguna tidak dibuat bingung apakah sistem memproses permintaan pengguna atau tidak [5], [6], [9], [14]. Kemudian, temuan masalah ketiga adalah ketidakjelasan informasi mengenai field mana yang wajib diisi dan field mana yang bersifat opsional, misalnya masalah pada fitur input jadwal praktek, tidak terdapat tanda yang membedakan bahwa field ini wajib diisi atau bersifat opsional. Untuk membedakan kedua jenis field, dapat ditambahkan tanda khusus kepada field wajib misalnya berupa tanda bintang [15], [16].

Pada prinsip heuristic kedua, yaitu kesesuaian antara sistem dan dunia nyata, ditemukan sebanyak tiga permasalahan yang masuk ke dalam kategori Minor. Permasalahan pertama adalah didapatkan tampilan beberapa prosedur yang rancu dan isi prosedur tidak menyampaikan hal-hal yang harus dilakukan oleh pengguna. Bahkan terdapat prosedur yang tidak memiliki isi apapun, seperti pada Prosedur Pengisian, Pengeditan dan Persetujuan KRS. Akan lebih baik jika prosedur-prosedur yang sudah tidak terpakai dihilangkan saja dari menu, sedangkan bagi prosedur-prosedur yang masih dipakai, isinya harus disesuaikan kembali dengan proses kerja yang sebenarnya terjadi agar tidak terjadi kebingungan di kalangan pengguna yang mengikuti prosedur dalam Portal Akademik [7], [17]. Masalah yang kedua adalah bahwa link-link yang berisi konten penting tersedia hanya di satu tempat saja sehingga pengguna harus mencari sendiri link yang berkaitan dengan tugas yang sedang dikerjakan. Hal ini tentu saja akan menyulitkan pengguna karena harus berpindah-pindah halaman ketika mengerjakan suatu tugas. Dengan demikian, sebaiknya Portal Akademik menyediakan link di beberapa tempat yang memang membutuhkan akses ke link tersebut. Ketiga, ditemukan masalah bahwa fitur yang seharusnya tidak dapat diakses oleh pengguna yang tidak memiliki hak akses namun fitur tersebut masih muncul di bagian menu sehingga pengguna yang tidak berhak masih bisa membuka dan mencoba fitur tersebut selayaknya pengguna yang memiliki akses walaupun kemudian sistem tidak menampilkan hasil. Untuk mencegah hal tersebut, sebaiknya fitur-fitur yang tidak boleh diakses oleh suatu pengguna di-hide saja pada tampilan pengguna bersangkutan.

Untuk prinsip heuristic yang ketiga, yaitu kontrol dan kebebasan pengguna, ditemukan sebanyak dua permasalahan yang masuk ke dalam kategori Major yaitu terdapat permasalahan yang mengganggu pengguna sehingga dibutuhkan perbaikan dengan prioritas tinggi. Masalah pertama yang ditemukan yaitu filter pencarian pada Portal Akademik masih sangat sederhana dimana pengguna tidak dimungkinkan untuk mengatur pencarian secara kompleks maupun menyimpan preferensi pencariannya. Pencarian yang disediakan oleh Portal Akademik hanya terbatas pada fitur-fitur tertentu dan field yang dapat dipilih sebagai kunci pencarian masih minim. Pencarian belum disediakan dalam bentuk advance search. Untuk mempermudah pengguna dalam melakukan pencarian, dapat ditambahkan fitur advance search dan berikan kebebasan kepada pengguna untuk dapat mengatur hasil pencarian dan field yang akan dipakai sebagai kunci pencarian [9], [15]. Permasalahan kedua adalah fungsi tombol Back yang tidak membawa pengguna kembali ke halaman asal. Misalnya pada saat pengguna membuka data mahasiswa melalui menu dosen wali, lalu pengguna membuka detail data mahasiswa yang tersusun dalam bentuk tab, ketika pengguna menekan tombol Back, sistem hanya mengubah alamat URL, akan tetapi tampilan halaman tidak ikut berubah. Apabila pengguna pernah memilih beberapa tab sebelumnya, tombol Back juga tidak membawa pengguna kembali ke halaman awal sebelum masuk ke tampilan data mahasiswa. Sebaiknya tombol Back ini diperbaiki agar bisa berfungsi sebagaimana mestinya mengingat pengguna membutuhkan cara yang mudah untuk kembali ke halaman sebelumnya [5], [7], [10], [17].

Dalam prinsip heuristic keempat, yaitu konsistensi dan standar, ditemukan sebanyak enam permasalahan yang masuk ke dalam kategori Minor. Permasalahan pertama yang diperoleh dari hasil evaluasi adalah informasi yang ditampilkan dalam Portal Akademik tidak relevan dan tidak up-to-date. Informasi yang disajikan tidak mengikuti perubahan yang telah diberitahukan kepada pengguna sebelumnya. Selain itu, terdapat halaman kosong yang muncul ketika pengguna mengklik suatu menu dimana hal tersebut dapat membingungkan pengguna karena 
tidak menemukan informasi yang dicari. Salah satu penentu kualitas informasi yang buruk yaitu data yang tidak lengkap. Dengan demikian, update informasi perlu dilakukan secara berkala dan lakukan pengecekan untuk membuang tampilan halaman yang kosong dengan mengacu pada aspek yang menentukan kualitas suatu informasi [5], [7], [12], [18]. Kedua, pencarian hanya terdapat di beberapa halaman tertentu dan hanya berlaku untuk halaman bersangkutan, sehingga pencarian hanya terbatas pada beberapa fitur, bukan mencakup keseluruhan Portal Akademik. Seharusnya fitur pencarian terdapat pada semua halaman situs sehingga pengguna bisa melakukan pencarian dari halaman manapun dimana hasil pencarian ini mencakup keseluruhan Portal Akademik untuk mencari informasi yang dibutuhkan [19]. Temuan masalah ketiga yaitu tidak terdapat perubahan warna pada link yang sudah pernah dikunjungi sebelumnya. Pada umumnya, warna link yang sudah pernah dikunjungi dengan link yang belum pernah dikunjungi akan dibedakan agar pengguna tahu mana halaman yang sudah pernah diakses dan mana yang belum [4], [20]. Permasalahan keempat adalah meskipun logo ditempatkan konsisten pada tempatnya, tetapi logo tersebut tidak dapat di-klik untuk membawa pengguna ke halaman beranda. Biasanya, logo berisi link untuk memudahkan pengguna mengakses halaman utama. Oleh karena itu, sebaiknya tambahkan link pada logo Portal Akademik agar pengguna bisa dengan mudah dan cepat kembali ke halaman utama [21]. Selanjutnya, masalah kelima yaitu tidak semua fitur yang dibutuhkan pengguna dapat dicetak ke printer, hanya fitur pengumuman saja yang dapat dicetak. Pada beberapa fitur, data hanya dapat di-ekspor ke file Excel dan tidak dapat langsung dicetak ke printer. Agar dapat mempersingkat waktu yang dibutuhkan pengguna untuk mencetak data, sediakan fitur untuk mencetak data secara langsung dari halaman Portal Akademik ke printer sehingga pengguna tidak perlu lagi mencetak melalui Excel [10]. Permasalahan terakhir yang ditemukan pada prinsip ini adalah Portal Akademik tidak menyediakan fitur pengaturan kata sandi pengguna. Jika pengguna ingin mengubah kata sandi, pengguna harus mengakses situs lain yaitu MISO (Mikroskil Single User Account). Sebaiknya Portal Akademik menyediakan link ke halaman MISO agar pengguna dapat melakukan pengaturan akun ataupun kata sandi [22].

Lalu, pada prinsip heuristic kelima yaitu pencegahan kesalahan, ditemukan sebanyak lima permasalahan yang masuk ke dalam kategori Major. Masalah pertama adalah terdapat beberapa fitur yang tidak berfungsi dengan baik seperti tombol Edit pada tampilan jadwal kuliah pengganti sehingga apabila terdapat kesalahan inputan data, jadwal tidak dapat diubah sendiri oleh pengguna tetapi pengguna harus menghubungi pihak pengelola Portal Akademik. Seharusnya dilakukan pengecekan semua fitur yang sudah dirilis kepada pengguna sehingga bisa dilakukan perbaikan terhadap fitur-fitur yang tidak berfungsi atau belum berfungsi dengan baik [7], [10], [17], [23]. Temuan masalah kedua yaitu Portal Akademik tidak memberikan notifikasi maupun mengubah tampilan ketika browser session sudah expired sehingga pengguna bisa tetap menginput data namun pada akhirnya data tetap tidak dapat disimpan. Hal ini mengakibatkan pengguna harus menginput ulang data. Untuk mengatasi hal tersebut, sebaiknya tambahkan notifikasi ataupun pemberitahuan kepada pengguna apabila session sudah expired agar pengguna tidak sia-sia melanjutkan tugas padahal session sudah expired dan datanya tidak tersimpan [5], [15]. Masalah yang ketiga adalah Portal Akademik tidak melakukan koreksi terhadap input data yang salah, hanya memberitahukan kesalahan pada penginputan. Selain itu, ketika terjadi salah input data, walaupun pengguna diberitahukan bahwa terdapat kesalahan, sistem tetap menyimpan inputan data yang salah. Oleh karena itu, direkomendasikan agar sistem mengarahkan pengguna untuk melakukan koreksi kesalahan dan juga melakukan konfirmasi terlebih dahulu kepada pengguna sebelum menyimpan data [9], [15], [24]. Permasalahan keempat yang ditemukan adalah Portal Akademik secara otomatis menyimpan inputan data pengguna walaupun pengguna belum menekan tombol Simpan. Hal ini perlu diperbaiki karena yang memiliki kuasa untuk menyimpan atau tidak menyimpan data adalah pengguna. Apabila pengguna tidak menekan tombol Simpan, maka seharusnya data tidak tersimpan [10], [15]. Masalah yang terakhir yaitu belum adanya notifikasi atau $e$-mail yang memberitahukan telah terjadi pergantian kata sandi kepada pengguna dimana hal ini dapat berakibat fatal jika bukan pengguna tersebut yang mengganti kata sandi. Misalnya, pengguna yang tidak bertanggung jawab sembarangan mengganti nilai mahasiswa setelah berhasil mengambil alih akun pengguna. Dengan demikian, sebaiknya keamanan Portal Akademik dapat ditingkatkan dengan mengirimkan notifikasi berupa e-mail kepada pengguna apabila terjadi pergantian password ataupun aktivitas yang janggal pada akun pengguna [5], [22].

Untuk prinsip heuristic yang keenam yaitu prinsip pengenalan alih-alih mengingat, ditemukan sebanyak empat permasalahan yang masuk ke dalam kategori Minor. Temuan masalah yang pertama adalah tidak tersedia alur proses kerja dalam tampilan Portal Akademik sehingga pengguna yang baru pertama kali berkunjung tidak tahu harus memulai dan mencari dari mana dulu karena terdapat beberapa tugas yang letaknya agak tersembunyi dalam menu. Akan lebih baik jika Portal Akademik menyediakan alur kerja untuk setiap proses yang terdapat pada Portal Akademik. Untuk membantu pengguna agar lebih mudah memahami alur proses tersebut, mungkin dapat ditambahkan gambar berupa diagram atau bagan alur kerja [7], [25]. Permasalahan yang kedua adalah pengguna harus mengingat informasi yang terdapat pada suatu tampilan kemudian memindahkan/menginput kembali informasi tersebut ke tampilan yang lain, seperti pada tampilan halaman Pengajuan Pergantian Judul Tugas Akhir, dosen harus mengingat NIM mahasiswa yang tersedia di tampilan halaman Berita Acara Bimbingan agar dapat mengajukan pergantian judul Tugas Akhir. Daripada memindahkan sendiri informasi tersebut dari tampilan yang satu ke tampilan lain, sebaiknya pada tampilan yang membutuhkan informasi ditambahkan fitur filter berdasarkan nama mahasiswa ataupun pencarian data mahasiswa sehingga dapat menghemat waktu pengguna [6], [15], [25]. Masalah ketiga adalah tidak tersedia cara untuk berpindah halaman dengan mudah, misalnya pengguna sedang berada di tampilan pengisian Berita Acara Ganjil dan ingin kembali ke tampilan Berita Acara Genap, maka 
pengguna harus memilih ulang tampilan dari awal dan tidak bisa langsung membuka tampilan Berita Acara Genap. Selain itu, pengguna juga tidak dapat secara langsung kembali ke halaman utama karena logo tidak berfungsi sebagai link ke halaman utama. Pada beberapa tampilan Portal Akademik, juga tidak tersedia tombol Back. Cara navigasi yang lebih mudah adalah dengan menambahkan link-link di semua halaman yang berhubungan dan juga menambahkan link pada logo sehingga pengguna bisa kembali ke halaman utama dengan cepat dan bisa mengakses halaman lainnya dengan mudah dari sana [21]. Terakhir, Portal Akademik tidak menyediakan site map sehingga untuk melihat keseluruhan konten, pengguna harus melihat dan mengeksplorasi sendiri dari menu navigasi. Oleh karena itu, direkomendasikan untuk membuat site map agar pengguna baru dapat lebih memahami navigasi dan fitur yang ada dalam Portal Akademik [26].

Berikutnya, pada prinsip heuristic ketujuh yaitu prinsip fleksibilitas dan efisiensi penggunaan ditemukan sebanyak empat permasalahan yang masuk ke dalam kategori Minor. Masalah pertama adalah belum tersedianya tampilan halaman yang dapat menampilkan banyak data sekaligus. Jika pengguna ingin melihat banyak data, maka pengguna harus membuka halaman satu per satu untuk melihat data yang dicari. Misalnya, ketika dosen wali ingin memantau IPK mahasiswa perwaliannya, dosen harus membuka satu per satu halaman data mahasiswa dan membuka pada tab Transkrip Nilai untuk melihat IPK mahasiswa sehingga mengurangi efektivitas kerja dosen. Untuk mengefektifkan pekerjaan pengguna, sebaiknya berikan kebebasan kepada pengguna untuk memilih dan menampilkan sendiri data-data yang dibutuhkan sekaligus dalam satu halaman sehingga waktu pengguna tidak terbuang sia-sia untuk hal yang tidak perlu [15], [17], [25]. Permasalahan kedua yang ditemukan adalah pengguna harus berulang kali memilih maupun menginput data yang sama karena Portal Akademik tidak menyimpan history inputan ataupun pilihan pengguna. Hal ini dapat dikurangi apabila Portal Akademik menyediakan fitur auto-fill sehingga ketika pengguna ingin mengisi data yang sama berulang-ulang, pengguna tidak harus mengetikkan kembali semua isi datanya, tetapi dapat dilengkapi oleh sistem. Sistem juga dapat menyediakan pilihan untuk menyimpan data default sehingga bisa mengurangi pengetikkan inputan data [9], [15], [25]. Temuan masalah ketiga adalah tidak terdapat instruksi, rincian, maupun petunjuk langkah berikutnya yang dapat diambil pengguna setelah menyelesaikan suatu proses dalam Portal Akademik. Sebaiknya Portal Akademik secara otomatis mengarahkan pengguna ke halaman berikutnya secara logis atau menampilkan pesan yang berisi rincian langkah berikutnya yang harus dilakukan oleh pengguna atau menampilkan pesan bahwa proses sudah selesai apabila tidak ada lagi yang perlu dilakukan oleh pengguna [5], [15], [25]. Masalah keempat adalah pengguna tidak dapat mengubah tampilan Portal Akademik sesuai dengan preferensi dan kebutuhan mereka. Dalam upaya membuat Portal Akademik terasa lebih personal bagi pengguna, lebih baik jika disediakan fitur untuk melakukan kustomisasi terhadap tampilan pengguna sesuai dengan preferensi dan kebutuhannya [14], [15], [17], [25].

Selanjutnya, pada prinsip heuristic kedelapan yaitu desain estetis dan minimalis ditemukan sebanyak dua permasalahan yang masuk ke dalam kategori Cosmetic yaitu permasalahan tidak terlalu mempengaruhi pengguna sehingga perbaikan tidak terlalu dibutuhkan jika waktu yang dimiliki terbatas. Permasalahan yang pertama ditemukan adalah sistem navigasi pada Portal Akademik bersifat mendalam dimana terdapat menu di dalam menu (tiap menu memiliki anak menu, bahkan hingga mencapai 4 level) sehingga untuk mengakses suatu menu yang berhubungan dengan tugas yang sedang dikerjakan, pengguna harus membuka satu per satu menu pada navigasi untuk mencari menu yang berkaitan dengan tugas. Dengan demikian, lebih baik jika menu yang berkaitan dengan tugas utama pengguna langsung disediakan sebagai menu utama pada navigasi bukan diakses setelah melalui beberapa level menu agar pengguna tidak perlu melakukan banyak klik untuk berpindah halaman [9], [19], [27]. Kemudian, masalah yang kedua yaitu halaman Portal Akademik terutama pada halaman berita dan prosedur berisi sekumpulan teks panjang yang membingungkan pengguna. Untuk membantu pengguna memahami berita ataupun prosedur yang baru, sebaiknya teks panjang tersebut didukung oleh gambar atau bagan yang bisa menjelaskan secara visual kepada pengguna karena umumnya pengguna lebih memilih melihat gambar yang bisa menyampaikan pesan dengan lebih singkat daripada penjelasan panjang lebar tentang suatu hal [17].

Pada prinsip heuristic kesembilan yaitu bantu pengguna mengenali, mendiagnosis, dan memulihkan dari kesalahan ditemukan sebanyak tiga permasalahan yang masuk ke dalam kategori Minor. Permasalahan pertama yang ditemukan evaluator adalah ketika terjadi error, pesan kesalahan yang ditampilkan hanya berisi kesalahan pada hasil inputan pengguna, namun tidak dijelaskan kapan dan dimana terjadi kesalahan, tingkat keparahan kesalahan, dan tidak dapat memberikan rincian kesalahan yang dilakukan pengguna jika diperlukan. Selain itu, pesan kesalahan hanya berupa pemberitahuan kesalahan yang dilakukan tanpa adanya instruksi mengenai tindakan yang harus dilakukan selanjutnya untuk memperbaiki kesalahan tersebut. Hal ini selayaknya diganti dengan pesan kesalahan yang lengkap dan informatif yang dapat menampilkan rincian kesalahan, tingkat keparahan, dan hal yang perlu dilakukan selanjutnya untuk memperbaiki kesalahan tersebut sehingga pengguna bisa mengatasi kesalahannya sendiri tanpa menghubungi pihak pengelola Portal Akademik [5], [7]-[9], [15], [28]. Masalah yang kedua yaitu apabila terdapat kesalahan ketika menginput data, Portal Akademik hanya memberikan pesan terjadinya kesalahan namun tidak memposisikan kursor pada lokasi yang salah secara otomatis. Selain itu, sistem juga melakukan penyimpanan terhadap data yang diinput oleh pengguna apabila pengguna menekan tombol Simpan walaupun kesalahan tersebut belum dikoreksi. Agar Portal Akademik bisa menyimpan data yang lebih akurat, selain menampilkan pesan kesalahan, sebaiknya Portal Akademik juga memposisikan kursor pada lokasi terjadinya kesalahan sehingga pengguna bisa mengetahui dan mengoreksi inputan datanya. Lalu, pastikan pula pengguna tidak dimungkinkan untuk melakukan penyimpanan data apabila masih ada data yang salah supaya tidak 
ada data-data yang tidak akurat yang diproses dalam sistem [4], [9], [15]. Masalah ketiga yang tidak kalah penting yaitu tidak tersedianya mekanisme pelaporan kesalahan apabila pengguna menemukan bug ataupun error pada sistem. Pengguna harus menghubungi pihak pengelola MIKA secara langsung ketika menemui masalah. Sudah selayaknya bug dan error yang ditemukan oleh pengguna diperbaiki agar Portal Akademik bisa menyediakan layanan yang memuaskan bagi pengguna. Oleh karena itu, sebaiknya disediakan fitur report bug untuk mempermudah pengguna melaporkan masalah yang ditemukan [5], [27].

Terakhir, pada prinsip heuristic bantuan dan dokumentasi ditemukan sebanyak dua permasalahan yang masuk ke dalam kategori Minor. Masalah yang pertama adalah pengguna dituntut harus mengetahui dimana letak fitur yang dibutuhkannya karena tidak terdapat demo, tutorial, FAQ maupun bantuan lainnya yang dapat membantu pengguna menggunakan Portal Akademik. Tidak semua pengguna baru bisa menggunakan Portal Akademik karena mereka belum terbiasa dengan tampilan Portal Akademik. Dengan demikian, sudah seharusnya ditambahkan panduan penggunaan dan FAQ pada Portal Akademik sehingga pengguna pemula pun dapat mempelajari cara menggunakan sistem melalui fitur bantuan yang telah disediakan [4]-[7], [9], [11], [14], [15], [29]. Permasalahan terakhir yang ditemukan evaluator yaitu tidak tersedianya kontak yang dapat dihubungi apabila pengguna mengalami kesulitan dan membutuhkan bantuan. Oleh karena itu, sebaiknya disediakan nomor telepon, e-mail atau kontak lainnya yang dapat memudahkan pengguna untuk mencari dan meminta bantuan yang dibutuhkan [4], [5], [15], [19], [29].

\section{KESIMPULAN}

Dengan demikian permasalahan yang paling mendesak untuk diperbaiki berada pada prinsip kontrol dan kebebasan pengguna serta prinsip pencegahan kesalahan. Rekomendasi perbaikan pada prinsip kontrol dan kebebasan pengguna mencakup penambahan fitur advance search dan perbaikan tombol Back agar dapat berfungsi dengan baik. Pengguna juga diberikan kebebasan untuk mengatur tampilan hasil pencarian yang dilakukan. Rekomendasi perbaikan pada prinsip pencegahan kesalahan antara lain melakukan uji coba pada fitur-fitur Portal Akademik Mikroskil sebelum dirilis kepada pengguna, serta menambahkan notifikasi, arahan, dan konfirmasi ketika pengguna melakukan suatu kegiatan.

Saran yang dapat diberikan untuk penelitian selanjutnya adalah:

1. Diharapkan dapat membuat rancangan tampilan antarmuka Portal Akademik Mikroskil berdasarkan rekomendasi perbaikan yang telah diusulkan.

2. Diharapkan evaluasi selanjutnya dapat melibatkan tampilan antarmuka dari sisi mahasiswa sehingga usability Portal Akademik Mikroskil dapat ditingkatkan.

3. Diharapkan dapat dilakukan evaluasi desain antarmuka secara berkala karena kebutuhan pengguna akan terus mengalami perubahan sesuai dengan perkembangan zaman.

\section{REFERENCES}

[1] J. Nielsen, "10 Usability Heuristics for User Interface Design,” Conference companion on Human factors in computing systems CHI 94, 1994.

[2] J. Nielsen, "Severity Ratings for Usability Problems," Nielsen Norman Group, 1995.

[3] J. Nielsen and R. Molich, "Heuristic Evaluation of User Interfaces," in Proceedings of the ACM CHI'90 conference on Human factors in computing systems, 1990 , pp. 249-256.

[4] P. Krisnayani, I. K. Resika Arthana, and I. G. Mahendra Darmawiguna, "Analisa Usability Pada Website UNDIKSHA Dengan Menggunakan Metode Heuristic Evaluation,” Kumpul. Artik. Mhs. Pendidik. Tek. Inform., 2016.

[5] R. Firmansyah, "Evaluasi Heuristik Pada Desain Interface Aplikasi My Indihome," Semin. Nas. Ilmu Pengetah. dan Teknol. Komput., 2016.

[6] D. Caesaron, "Evaluasi Heuristic Desain Antar Muka (Interface) Portal Mahasiswa (Studi Kasus Portal Mahasiswa Universitas X),” J. Metris, 2015.

[7] M. I. Sya'roni, A. P. Kharisma, and F. Amalia, "Perbandingan Hasil Metode Evaluasi Usability Antara Heuristic Evaluation dengan Think Aloud pada Kasus Web FILKOM APPS untuk Mahasiswa,” J. Pengemb. Teknol. Inf. dan Ilmu Kompuer, 2018.

[8] A. P. Kristianto, M. Mahmudi, and H. Henderi, "Analisis usabilitas sistem informasi driver pt. gojek indonesia berdasarkan pendekatan evaluasi usability heuristik," Semin. Nas. Teknol. Inf. dan Multimed. 2018, 2018.

[9] S. I. Irwan, I. S. Sitanggang, and B. Mustafa, “Analisis Usabilitas Sistem Informasi Manajemen Penerimaan Koleksi Deposit Di Perpusnas Berdasarkan Pendekatan Evaluasi Heuristik," vol. 14, no. 1, pp. 33-42, 2015.

[10] B. A. Mustikaningtyas, M. C. Saputra, and A. Pinandito, "Analisis Usability Pada Website Universitas Brawijaya Dengan Heuristic Evaluation," J. Teknol. Inf. dan Ilmu Komput., 2016.

[11] J. S. Mtebe and M. M. Kissaka, "Heuristics for evaluating usability of Learning Management Systems in Africa," in 2015 IST-Africa Conference, IST-Africa 2015, 2015.

[12] J. M. Toribio-Guzmán, A. García-Holgado, F. Soto Pérez, F. J. García-Peñalvo, and M. Franco Martín, "Usability Evaluation of a Private Social Network on Mental Health for Relatives," J. Med. Syst., 2017.

[13] D. Powazek, "Where Am I?," 2006. [Online]. Available: http://alistapart.com/article/whereami/.

[14] D. Fadeyev, "User Interface Design - 12 Useful Techniques," $2009 . \quad$ [Online]. Available: https://www.smashingmagazine.com/2009/01/12-useful-techniques-for-good-user-interface-design-in-web-applications/.

[15] B. Shneiderman, C. Plaisant, M. Cohen, S. Jacobs, N. Elmqvist, and N. Diakopoulos, Designing the User Interface: Strategies for Effective Human-Computer Interaction, 6th Editio. Pearson, 2016.

[16] D. Fadeyev, “10 Useful Usability Findings and Guidelines,” $2009 . \quad$ [Online]. Available: https://www.smashingmagazine.com/2009/09/10-useful-usability-findings-and-guidelines/. 
[17] V. Friedman, “10 Principles Of Good Website Design,” 2008. [Online]. Available: https://www.smashingmagazine.com/2008/01/10principles-of-effective-web-design/.

[18] W. H. DeLone and E. R. McLean, "The DeLone and McLean model of information systems success: A ten-year update," in Journal of Management Information Systems, 2003

[19] V. Friedman, "30 Usability Issues To Be Aware Of," 2007. [Online]. Available: https://www.smashingmagazine.com/2007/10/30usability-issues-to-be-aware-of/.

[20] J. Hensley, "Improve Your Designs With The Principles Of Similarity And Proximity (Part 1)," 2016. [Online]. Available: https://www.smashingmagazine.com/2016/05/improve-your-designs-with-principles-similarity-proximity-part-1/.

[21] H. Loranger, "Homepage Links Remain a Necessity," 2017. [Online]. Available: https://www.nngroup.com/articles/homepage-links/.

[22] D. Pinsky, "11 Website Design And Development Best Practices For 2018," 2018. [Online]. Available: https://www.forbes.com/sites/denispinsky/2018/02/12/website-design-standards/\#23f38218f54f.

[23] I. Ghiciuc, "There is no such thing as Bug Free Software, not even in the Big League," 2013.

[24] E. McKay, "Are you sure? How to Write Effective Confirmations," $2010 . \quad$ [Online]. Available: http://www.uxdesignedge.com/2010/06/are-you-sure-how-to-write-effective-confirmations/.

[25] S. Widen, "The Science Behind UX Design," 2017. [Online]. Available: https://www.forbes.com/sites/forbesagencycouncil/2017/01/09/the-science-behind-ux-design/\#22dabacc5ca9.

[26] J. Cardello, "The Modern Web Design Process: Creating Sitemaps and Wireframes," 2017. [Online]. Available: https://webflow.com/blog/the-modern-web-design-process-creating-sitemaps-and-wireframes.

[27] S. Stiner, "Five User Experience Tips For Software Developers," 2017. [Online]. Available: https://www.forbes.com/sites/forbestechcouncil/2017/01/31/five-user-experience-tips-for-software-developers/\#229d937e24d5

[28] J. Nielsen, "Error Message Guidelines," 2001.

[29] P. Hodgson, "Tips for Writing User Manuals," 2007. 